\title{
The effects of environmental, social and governance disclosures and performance on firm value: a review of the literature in accounting and finance
}

Article

Accepted Version

Creative Commons: Attribution-Noncommercial-No Derivative Works 4.0

Brooks, C. and Oikonomou, I. (2018) The effects of environmental, social and governance disclosures and performance on firm value: a review of the literature in accounting and finance. The British Accounting Review, 50 (1). pp. 1-15. ISSN 0890-8389 doi:

https://doi.org/10.1016/j.bar.2017.11.005 Available at https://centaur.reading.ac.uk/74071/

It is advisable to refer to the publisher's version if you intend to cite from the work. See Guidance on citing.

To link to this article DOI: http://dx.doi.org/10.1016/j.bar.2017.11.005

Publisher: Elsevier

All outputs in CentAUR are protected by Intellectual Property Rights law, including copyright law. Copyright and IPR is retained by the creators or other copyright holders. Terms and conditions for use of this material are defined in the End User Agreement. 


\section{www.reading.ac.uk/centaur}

\section{CentAUR}

Central Archive at the University of Reading

Reading's research outputs online 
The Effects of Environmental, Social and Governance Disclosures and Performance on Firm Value: A Review of the Literature in Accounting and Finance

\author{
Chris Brooks and Ioannis Oikonomou \\ ICMA Centre, Henley Business School, University of Reading*
}

November 2017

Forthcoming, British Accounting Review 2018

\begin{abstract}
This paper not only attempts to survey the burgeoning literature on environmental, social and governance disclosures and performance and their effects on firm value, but its focus also lies on highlighting stylised observations coming from the most recent work that has not yet become part of the 'conventional wisdom' in the field. In addition, it outlines some of the crucial knowledge gaps and interesting questions that have not, as of yet, been addressed and thus outlines a potential agenda for future research on socially responsible investing. Lastly, it introduces the papers published in this special issue of the British Accounting Review.

* Correspondence to Ioannis Oikonomou, ICMA Centre, Henley Business School, University of Reading, Whiteknights, Reading, RG6 6BA, UK; E-mail: i.oikonomou@icmacentre.ac.uk
\end{abstract}

Keywords: Corporate social responsibility (CSR); Environmental, Social and Governance (ESG) disclosures; firm value; stock market performance; literature review; socially responsible investing (SRI); ethical investing.

J.E.L. Classifications: G19, M14.

\title{
Acknowledgements
}

We would like to thank the Joint Editors, Alan Lowe and Nathan Joseph, for permitting us the opportunity to organise this special issue and we are also grateful to Lisa Schopohl for research assistance. Finally, we thank the contributors who have provided their work for this issue. 


\section{Introduction}

The empirical literature on the relationship between Corporate Social Responsibility (CSR) and Financial Performance (FP) has a long and rich history. The question of whether directly promoting societal and environmental good can also lead to beneficial economic outcomes for the related business entity has been identified as a crucial one for over four decades. The possibility of the existence of a financial impetus for responsible corporate behaviour is sufficient to reposition the debate from the sphere of moral philosophy and business ethics to that of modern economics. The formation and evolution of stakeholder theory (Freeman, 1983) and its instrumental aspects in particular (Jones, 1995) has provided the foundation for proponents of CSR to theorise that CSR can help in building and solidifying trusting relationships with a variety of constituents (employees, consumers, local communities, environmental activists and concerned citizens among many others) that are important to the firm's long term success and financial standing.

Not all scholars have been of the view that good social performance has financial benefits for firms, however. Historically, the eminent economist Milton Friedman has been one of the most outspoken opponents of CSR. In his famous article entitled 'The social responsibility of business is to increase its profits', published in 1970, he argued that the application of CSR imposes an unjustified and fundamentally undemocratic taxation on shareholders, that its implementation costs outweigh any potential tangible benefits and that due to this, it constitutes a misallocation and misappropriation of valuable company resources (Friedman, 1970).

Based on these two opposing views (and every other one that falls within the spectrum they define), academics in the fields of, inter alia, strategic management, marketing, environmental economics, business ethics and finance have empirically investigated many different angles regarding the extent to which CSR can lead to demonstrably superior firm financial performance or not. Recently, the increased attention the general public has given to the notion of CSR and the corresponding growth of the Socially Responsible Investment (SRI) industry have provided academia with an even greater incentive to delve deeper into the alleged link between CSR and FP over the last 20 years.

It is not just the size but also the breadth of the CSR-FP literature that is of relevance. Griffin and Mahon (1997) made a series of observations concerning the diversity and variability of the characteristics of the related body of work of their time in order to make the argument that the majority of empirical findings are simply incomparable with each other. This argument has 
only been strengthened over the years (Malik, 2015). Studies on the relationship between CSR and FP are characterised by:

i. different definitions and formulations of both CSR and FP,

ii. hypotheses built on theoretical frameworks that at times oppose one another

iii. datasets with different features with regard to: the CSR dimension of interest; the nature and scale of the FP measure used; the asset class in which the relationship is investigated; the industry, country and timeframe in focus.

iv. the application of diverse econometric methodologies.

Due to all of these factors, high level conclusions that can be used to provide a bird's eye view of the field to the interested academic or practitioner have been hard to draw. This is unfortunate as the inherent difficulty of the task at hand becomes more pronounced by the lack of literature reviews that attempt to effectively summarise what we know from all the research that has been conducted in the field and, equally importantly, what we do not know and need to find out.

The explosive growth of public interest in CSR combined with the respective growth of the SRI industry and related academic research create an essential need for a critical, up-to-date summary of the SRI literature, which this paper aims to provide, along with an introduction to the papers published in this special issue of the British Accounting Review.

The remainder of the paper is structured as follows. Section 2 begins by defining some concepts and explaining what is usually referred to by the term 'social disclosure'. Section 3 then proceeds to discuss the literature on the links between social disclosure and firm performance in the CSR arena. Section 4 begins the discussion of the relationships between the social performance of firms and their financial performance, focusing on accounting-based measures. Section 5 then continues by examining the link between the financial impact of different CSR dimensions on stock market performance at the individual firm level. Section 6 focuses on research concerning the performance of SRI portfolios, funds and indices while Section 7 discusses some of the stylised observations coming from the most recent strands of research in the field. Finally, Section 8 concludes by highlighting some of the unexplored aspects of the SRI agenda and introduces the papers contained in this special issue, which attempt to fill part of these gaps. 


\section{What is 'Social Disclosure'?}

Social disclosure may be defined as any information that a firm makes public, typically within or alongside its annual accounts or in a stand-alone report, that relates to its performance, standards or activities under the corporate social responsibility umbrella. ${ }^{1}$ Such documents are most commonly known as sustainability reports, but they are also variously known as corporate social responsibility reports, eco-reports, and corporate accountability reports. ${ }^{2}$ The documents are believed to convey important information regarding the extent to which a firm's activities are sustainable, defined as one which can service the needs of all its stakeholders without limiting its ability to meet the needs of any potential future stakeholders by maintaining its base of environmental, social and economic capital (see Dyllick and Hockerts, 2002).

Social disclosures may be mandatory - a legal requirement to deliver this information - or voluntary, where the extent and nature of reporting may vary substantially between firms. Over time, mandatory reporting requirements have been introduced in a wider variety of countries as disclosure regulations have developed, and this resulted in a predictable increase in disclosure levels in the affected countries (Ioannou and Serafeim, 2016). Countries with mandatory sustainability disclosure rules now include Brazil, China, Denmark, Hong Kong, India, Malaysia and South Africa, with most of these introducing their respective legislation in the late 2000s. However, mandatory and complete sustainability reporting for all firms still appears a long way off since the disclosure regulations are typically introduced on a 'comply or explain' basis, where firms have a get-out clause that enables them not to make disclosures provided that they justify their position. The potential sanctions for failing to comply are also likely to be much weaker than for comparable non-reporting of the conventional financial accounts (Ioannou and Serafeim, 2016). Despite this, the United Nations is recommending that all large firms be mandated to publish sustainability reports by $2030 .^{3}$ In their social and environmental reporting beyond mandatory requirements, firms can either be pro-active -

\footnotetext{
${ }^{1}$ A widely accepted definition of corporate social responsibility was drafted by the European Commission as 'the responsibility of enterprises for their impacts on society [and] to integrate social, environmental, ethical, human rights and consumer concerns into their business operations and core strategy' - see European Commission (2011) A Renewed EU Strategy 2011-2014 for Corporate Social Responsibility, Brussels, p.6. ${ }^{2}$ To further add to the confusion of terminology, the phrases 'social reporting' and 'environmental reporting' are often used interchangeably in the literature despite the obvious differences in the more precise meanings that could be attributed to each.

${ }^{3}$ United Nations (2013) UN Panel Call for Global Sustainability Reporting.
} 
voluntarily going beyond minimal stakeholder expectations, or re-active - responding to social pressures when and to the degree that they arise (see Norris and O'Dwyer, 2004).

Gray et al. (1995, p.49) argued that at the time they were writing, social reporting 'did not appear to be a systematic activity', and interest in making non-mandatory disclosures rose and fell as with any fashion, echoing Puxty's (1991) sentiment that it was not an activity that most companies considered important. Practices varied across countries as well as over time (Andrews et al., 1989; Guthrie and Parker, 1990; Teoh and Thong, 1984). Gray et al. (op cit.) also observe that in the UK, both the percentage of companies making disclosures within their annual accounts and the extent of the information they present both increased substantially between the 1970s and 1990s with a particular growth in community and environmental disclosures in addition to employee-related disclosures which were already prevalent. However, as Maltby (2004) notes in her study of a UK-based steelmaker in the early $20^{\text {th }}$ century, making CSR disclosures is certainly not the relatively new phenomenon that many contemporary writers presume, but has taken place, albeit selectively, for over a century.

What are firms reporting and how has this changed over time? In their single firm case studies of early $20^{\text {th }}$ century firms in the US, UK and Australia respectively, Hogner (1982), Maltby (2004) and Guthrie and Parker (1989) find that firms were predominantly reporting on social values and on conditions and safety for workers, with much less prevalence for environmental issues such as pollution. The more recent historical development of sustainability reporting is charted by, amongst others, Hahn and Kühnen (2013, p.5). In the 1970s, 'social reports' were sometimes produced to supplement conventional financial reports, whereas attention to environmental matters, including emissions and waste, took precedence in the 1980s. By the late 1990s, joint reports including both environmental and social information alongside financial reports began to emerge following the Global Reporting Initiative (GRI) programme and this trend continues (Kolb, 2010). Most recently, fully integrated reports have been produced that incorporate economic, social and environmental information in a single document to provide a complete picture of the firm's activities with South Africa leading the way (Adams and Simnett, 2011).

A key problem that has beset the literature has been the absence of a broadly accepted theoretical perspective on why firms should engage in social reporting and what its effects will be on the various stakeholder groups (Ullman, 1985). Thus, much of the scholarly discourse in this area was, and continues to be, philosophical in nature, examining the role of social 
accounting in society and organisations, and dealing with issues relating to the sustainability of the modern corporate environment. Such research raises normative questions concerning the extent to which accounting academics should engage with and further the debates on the societal and environmental problems caused by corporations (e.g., Bebbington and Thomson, 1996; Gray, 2002; Gray and Bebbington, 2000; O’Dwyer, 2001).

\section{Why do Firms Make Voluntary Social Disclosures?}

Why should firms present social and environmental information in their annual accounts beyond that required by law? Matthews (1997) highlights three possible explanations: a sense of 'social contract', to enhance their legitimacy and to enhance their financial valuations. Legitimacy relates to the notion that firms came under increasing pressure to be seen to operate in a way that shows respect for society and the environment in fitting with the political backdrop during the 1960s and 1970s (Roberts, 1992). For the firm concerned, gaining such legitimacy 'both lessens the regulatory burden that would otherwise constrain the execution of corporate strategy, and keeps from the market the potential stigma associated with a reputation for environmental recklessness' (Brammer and Pavelin, 2006, p. 1169). According to Hahn and Kühnen (2013), a long list of potential business benefits may accrue to firms which present sustainability information, including the enhancement of transparency, improving reputation and brand value, motivating employees and supporting the firm's control processes.

A possible link with financial performance, which we discuss extensively below, may arise through firms being proactive in giving the impression of doing good by publicising those parts of their operations which meet or exceed stakeholder explanations. ${ }^{4}$ The latter position has led CSR to be viewed with scepticism from some observers who believe that such firms' motives are less than sincere, raising the spectre of 'greenwashing' where firms improve social performance for purely presentational reasons and not to improve underlying sustainability, thus doing the right thing for the wrong reason (Schaltegger and Burritt, 2010, p.378), or worse, deliberately advertising good performance on some aspects of CSR while burying poor performance on others (see Owen et al., 2001).

Equally cynically, Brammer and Pavelin (2006, p.1169) argue that the primary purpose of corporate disclosure is to 'influence perceptions regarding the future financial prospects of the firm in the minds of external, primarily financial, stakeholders' rather than to genuinely attempt

\footnotetext{
${ }^{4}$ These arguments are nicely summarised in Maltby (2004).
} 
to reduce environmental or social damage (see also Aerts and Cormier, 2009; Frost et al, 2005). There is also evidence that when disclosures are voluntary, firms will only supply a judiciously selected portion of information that presents them in a positive light in a self-congratulatory way (Hodder-Webb et al., 2009), which raises questions about the completeness of corporate social disclosures (Moser and Martin, 2012) and a requirement for assurance of such reports (Simnett et al., 2009).

A thread of the literature even goes so far as to argue that corporate 'sustainability reporting' has nothing to do with sustainability, but rather represents an attempt to frame the discussion around how firms would like to interpret sustainability in line with their own interests (Gray, 2010). In the spirit of the critical perspective, this line of argument is that sustainability reporting does more harm than good, requires a more radical replacement, and is 'a fad that will disappear in time' (Burritt and Schaltegger, 2010, p. 829). Yet as Burritt and Schaltegger note, this viewpoint cannot solve practical management problems and a more pragmatic perspective is required for firms to have a way to move forward.

\section{The Relationship Between Social Disclosure and CSR Performance}

Clarkson et al. (2008) suggest that two strands of theory predict opposing signs for the link between voluntary environmental disclosure and environmental performance. They argue that economic theories of disclosure, taking an instrumentalist view of the firm's behaviour (see also Dye, 1985), predict a positive relationship between the two as good environmental performers will be desirous of sending an appropriate signal of their status, which will be hard for weaker performers to imitate, to investors. On the other hand, legitimacy and stakeholder theories, arising more from political and sociological than economic perspectives, would lead to a negative correlation so that weak performers have greater incentives to disclose in order to enhance their legitimacy and persuade stakeholders that their actual behaviour is better than perceived. We might view there being a third strand of theory based on pure ethical theories where firms should demonstrate good social and environmental performance simply because it is morally the right thing to do, irrespective of the business case for or against it (Carroll, 1979; Jones, 1995).

Significant dangers may ensue for firms which hide or distort the truth of a bad social or environmental performance who may then be subject to adverse publicity, lobbying, or boycott campaigns by consumer or pressure groups (Roberts, 1992; Sinclair- Desgagné and Gozlan, 2003) or divestment by socially responsible investors (Willis, 2003). 
Sustainability accounting is defined as an approach whereby appropriate costs are deducted from accounting profits to cover the outgoings necessary to ensure that the stock of natural capital is not depleted (see Bebbington and Gray, 2001). ${ }^{5}$ It was borne of the frustration which some accounting academics felt with the narrow profit maximising agenda that gave no formal consideration to social or environmental concerns (e.g., Gray and Bebbington, 2000; Maunders and Burritt, 1991) and the assumption that monetary valuation is always possible (Milne, 1996). This process was given additional prominence and formality by the establishment of a set of Sustainability Accounting Guidelines as part of the GRI in 2002, providing a set of measures under three headings: economic, environmental and social that lead to the 'triple bottom line' term. ${ }^{6,7}$ Lamberton (2005) traces the development of the literature on sustainability accounting and proposes a conceptual framework for it within the standard financial accounting context while a broad and comprehensive review of the literature in this area is presented in Hahn and Kühnen (2013).

Producing sustainability disclosures that have real measurable content involves expending resources to put the appropriate mechanisms in place to measure, collect and report the relevant information (Buhr, 2002; Cormier and Magnan, 1999). Therefore, we would expect that firms would elect to make sustainability disclosures if the expected benefits outweigh the costs. From this perspective, we would expect firms with good social and environmental performance would make more detailed and more extensive voluntary disclosures; weak performers on this measure may believe it safer to devote minimal space to such disclosures for fear of offering potential litigants additional rope with which to hang them, although a lack of transparency may also harm their standing as, in the absence of any information, stakeholders could fear the worst. There is some evidence to support this line of reasoning. For example, focusing specifically on carbon disclosure, a voluntary activity following the Carbon Disclosure Project (CDP) ${ }^{8}$ Luo and Tang (2014) use a large multi-country sample and find a positive correlation

\footnotetext{
${ }^{5}$ Sometimes 'sustainability accounting' is simply used as a fashionable replacement for the term 'environmental accounting' (Schaltegger and Burritt, 2010, p.377).

${ }^{6}$ The GRI was initially established in 1997 by the United Nations Environmental Programme jointly with the Coalition for Responsible Economies. It was published in 2002 with the aim of developing a standardised, worldwide structure for sustainability reporting - see GRI (2002) Sustainable Reporting Guidelines.

${ }^{7}$ The GRI is focused primarily on the environmental and social pillars with the conventions for presenting the economic dimension left largely to the conventional financial report (Hahn and Kühnen, 2013).

${ }^{8}$ The CDP is a voluntary, self-contained carbon statement in a standardised format.
} 
between voluntary carbon disclosure and environmental performance, echoing the earlier findings of Freedman and Jaggi (2004) who used a narrower sample of US utility firms. ${ }^{9}$

These trade-offs are likely to vary by industry and with company attributes such as size, management structure and approach (e.g., Cormier and Magnan, 1999), and with the value of a firm's reputational capital and the strength of its media presence (e.g., business-to-business versus business-to-customer firms - see Brown and Deegan, 1998). Firms with strong reputations may consider introducing sustainability reports to be a form of insurance to protect the value of their brands. In addition, large firms may be more inclined to make voluntary disclosures since they have the scale over which to spread relatively fixed information production costs. Large firms also create a greater environmental and societal footprint and face greater public scrutiny due to their enhanced visibility (Fortanier et al., 2011). On the other hand, heavily indebted or highly leveraged firms may have impaired ability to bear the costs of sustainability reporting and similarly those with old assets which are likely to embody older technologies producing greater pollution are less likely to report ((Stanny and Ely, 2008).

Companies in certain industries (e.g. heavy polluters) may have sector-specific expectations of high reporting standards (Cormier and Magnan, 1999; Parsa and Kouhy, 2008), while, intuitively, listed firms are more likely to report environmental and social information than those which are unlisted (Haddock, 2005). Finally, some countries have stricter mandatory sustainability reporting requirements than others - for instance in Denmark, Norway and Sweden, firms must report on environmental effects (Hess and Dunfee, 2007). It would be possible to overplay the cross-country differences in reporting patterns, however, since a study by de Villiers and Alexander (2014) shows very similar disclosure practices along almost all dimensions among Australian and South African mining companies, despite the obvious differences in societal and environmental problems.

Empirically, Brammer and Pavelin (2006) examine the factors that affect the quality and quantity of environmental disclosures in a cross-sectional sample of large, UK companies. They show that, perhaps counter-intuitively, firms with bad environmental performance are no more likely than others to make an environmental disclosure, but when they do, it will be carefully nuanced to minimise the likelihood of adverse reactions.

\footnotetext{
${ }^{9}$ Using different methodologies and countries, Freedman and Jaggi (2011) were unable to uncover any such relationships.
} 
Examining the environmental disclosures of firms drawn from five high pollution industries in the US in 2003, Clarkson et al. (2008) observe a positive relationship between environmental performance and environmental disclosure, consistent with the signalling hypothesis under the umbrella of economic justifications. CSR reports may thus act as a commitment device that binds the firm to continuing to behave ethically (Boot et al., 1993). However, at the same time Clarkson et al. also argue that there is support for socio-political theories in the sense that firms with poor environmental performance reported in the media subsequently seek legitimacy by making disclosures, but are of a form that is hard for stakeholders to verify or refute.

Patten (2002) suggests that the inconsistency in the findings of research concerning the empirical link between environmental performance and disclosure can be ascribed to a litany of methodological problems that beset studies up to that point, including problems with measurement of both key variables, sampling issues and a lack of control variables. A further issue is the blurring of mandatory and discretionary disclosures by many authors. For example, matters such as toxic waste damage, environment-related fines or oil spills, are not discretionary, and tend to be serious in nature. Therefore, such disclosures may be perceived in a markedly different way by stakeholders compared with the voluntary offering of additional environmental or social information in annual accounts, where proactive firms may wish to voluntarily signal their good performance (Clarkson et al., 2008).

There are suggestions in the literature that engaging in sustainability reporting leads to an improvement in CSR performance as it then becomes a measurable activity that is visible to external stakeholders (Topping, 2012). Christensen (2016) finds that firms which make voluntary disclosures have a lower probability of being involved in future misconduct that leads to lawsuits (e.g., for discrimination or bribery), especially for more complex organisations. Moreover, he finds that companies which made CSR disclosures experience more modest stock price declines in the event that they are involved in such a misconduct scandal as previously good behaviour afforded them a degree of protection.

\section{The Link between Disclosure and Accounting Measures of Financial Performance}

As Waddock and Graves (1997) note in their highly-cited paper, it is possible to argue for a positive link between CSR performance and firm financial performance, a negative link between the two, or no link at all. A positive link will occur if firms with good CSR are, for 
instance, better able to recruit and hold onto talented workers (e.g., Greening and Turban, 2000), and may benefit from reputational insurance to minimse the damage wrought by any transgressions (Peloza, 2006).

A negative link would occur if expenditure - both financial and in terms of managerial time and focus - on CSR activities is value-destroying because resources spent on such activities are not met by increased revenues and such activities distract managers from enhancing the firm's core business. Campbell (2007) develops a 'slack resources theory' where firms with a surplus of current resources may be inclined to spend some of these on CSR-related activities. Consistent with this theory, Qiu et al. (2016) find that profitable firms are more likely to make social disclosures or combined social and environmental disclosures in the following year.

Finally, no discernible link between CSR and financial performance may be the result if either there are positive and negative effects which net off (or if the value-creating potential of CSR varies across firms so that for some the benefits exceed the costs but vice versa for others) or simply because it is an irrelevance with trivial impacts on both costs and revenues compared to other factors that have a more direct impact on the firm's core business activity.

A large number of studies have investigated whether environmental disclosures have so-called value relevance for investors, although the number of comparable papers focusing on social disclosures more narrowly defined is much smaller (Cormier et al., 2011; Qiu et al., 2016). This is perhaps surprising since social disclosures are likely to be of even more concern to internal stakeholders and especially current and potential employees, who will be directly affected by issues such as diversity, discrimination, worker safety etc. The lack of evidence in this area might thus relate more to the relative difficulty in obtaining relevant data than for the environmental case.

Early research focused on whether there existed a contemporaneous link between social reporting and financial performance measured narrowly using profitability, but was largely unable to uncover any such relationship (Abbott and Monsen, 1979; Belkaoui and Karpik, 1989; Freedman and Jaggi, 1988). However, there were several exceptions, including Bragdon and Marlin (1972) who found that environmental performance ratings for paper-making firms were positively correlated with their profitability, and Roberts (1992), who observed social reporting to be a positive function of lagged profitability. 
It is also possible that the link between social disclosures and profitability has changed over time, as socially irresponsible business practices which were once commonplace have gradually become considered unacceptable among stakeholders as both the regulatory environment and societal expectations have raised the bar.

In an important cross-sectional study using 1990-91 data on the link between social and financial performance using the KLD database of Kinder, Lyndenberg and Domini (KLD) to measure the former, Waddock and Graves (1997) use three accounting variables: return on assets (ROA), return on equity (ROE) and return on sales (ROS), to measure the latter. They find that one-year lagged CSR has significant explanatory power for ROA, limited power for ROS and none for ROE. On the other hand, they also find from separate regressions that lagged accounting variables all have significant explanatory power for next year's CSR figures. This, they conclude, is potential evidence for a virtuous circle where firms 'do well by doing good'. This mirrored earlier findings by Stevens (1984) using an event study approach that showed firms reporting higher environmental damage mitigation costs experienced significantly lower returns than those reporting lower costs.

Early empirical work on the link between corporate social and financial performance probably suffered from an endogeneity problem - although the investigations focused on whether a particular CSR or disclosure policy affected financial performance (the so-called 'good management theory'), it is also possible that good performance on CSR grounds is more likely to arise when a firm is financially in a strong position and thus has the luxury of spare resources to expend on CSR-related activities (the 'slack resources theory') - see Waddock and Graves (1997). A third possibility is that causality runs in both directions so that good social and financial performance support each other in a virtuous circle (Nelling and Webb, 2009). Firms may make voluntary disclosures to limit the information asymmetry that exists between stakeholders that are internal and external (Healy and Palepu, 2001) and in so-doing, reduce their cost of capital (Frankel et al., 1995).

An additional issue is the timing of any causal relationship. Lys et al. (2015) suggest that firms increase expenditure on CSR when they expect better financial performance in the future, arguing that previous findings omitted a key variable from their regressions, namely the private information that managers possess about the likely future financial performance of their firms.

Al-Tuwaijri et al. (2004) examine the link between environmental disclosure, environmental performance and economic performance within a cross-sectional simultaneous equations 
approach using US data, finding that estimates of the relationship can be severely biased if the endogeneity is not accounted for, possibly explaining the mixed results in previous examinations of the (pairwise) links between the three variables. This enables them to capture the effect on all three variables of the overarching management strategy (Ullmann, 1985). AlTuwaijri et al. find that the three variables are strongly positively related.

It does appear to be the case that good CSR has a more beneficial effect on accounting performance measures than on their stock prices. For example, Chopra and $\mathrm{Wu}(2016)$ find that environmental performance (measured using news searches linking each firm with environmentally positive activities) is positively correlated with improved operating performance for US firms in the computer and electronics sector over the long term. This is consistent with Hart's (1995) natural resource-based theory that the take-up of efficient new technologies is competitively beneficial to firms. They argue that since many of the improvements in environmental behaviour were regulatory requirements rather than voluntary, they increased firms' costs but revenues grew by more and thus it took two years for the investment to pay off with initial losses on these activities occurring prior to report in the news story. Further, Russo and Fouts (1997) find that good environmental performance led to higher ROA and additionally, Kassinis and Soteriou (2003) observed that good environmental performance improved revenues, market share and profitability as a result of increased product demand and customer loyalty.

Against these positive findings, Qiu et al. (2016) are unable to identify any link between environmental disclosures and profitability for a broad sample of UK firms, although they suggest that this may relate to possible noise in their environmental performance measure. They do observe, however, that firms making social disclosures have higher market values, which they attribute to higher anticipated future cashflows.

Increases in mandatory reporting may be expected to adversely affect profitability by increasing costs since, if firms behave rationally, they should automatically report whenever it is in their best interests to do so: disclosure regulation means that high performing firms will have to work even harder to signal their superiority and weak performing firms will be forced to raise their standards, playing away from their strengths. Yet Ioannou and Serafeim (2016) find that the increases in reporting following new regulations has increased firm valuations as measured by Tobin's Q. This runs directly against the neoclassical view that environmental and social regulation will increase production costs and thus reduce profitability (Patten, 2002). 
Intuitively, one might also think of tax payment as being an aspect of CSR performance since a stated commitment to act responsibly might implicitly be expected to extend to a commitment not to take deliberate actions to avoid taxes that are due, and recent media discussions have certainly portrayed this view. Tax avoidance practices reduce government revenues, hence are costly to society and may therefore be viewed as inconsistent with CSR (Hoi et al., 2013).

In a highly cynical article regarding firms' motivations for engaging in socially responsible behaviour, Sikka (2010) argues that there exists a glaring inconsistency between the policy documents that companies draft avowing their intention to behave in a socially responsible manner on one hand but their participation in schemes to avoid tax on the other, which he views as 'organised hypocrisy'. He suggested that many companies do not see the payment of taxes as a social duty and a return to society's investment of social capital, but rather it is viewed as a burdensome cost (Sikka, p. 156). He continues that CSR statements constitute a shallow attempt to protect the firm from reputational damage that may arise from media or NGO scrutiny of any dubious practices that they may be involved in. So firms may seek to increase their standing regarding social responsibility as a means of protection so that any tax-related transgressions that become public do less reputational damage. Thus it is possible that firms could use a strong performance on CSR grounds and/or sustainability disclosures as a way to 'greenwash' over other areas where their behaviour is less savoury - for example, where they engage in earnings management (e.g., Hemingway and Maclagan, 2004), although this view is contested (e.g., Hasseldine and Morris, 2013). However, the bulk of the evidence is suggestive that social and financial behaviours operate in tandem, so that firms with a good social performance are less inclined to engage in earnings management via discretionary accruals or by distorting their real operations and are more likely to be transparent (e.g., Hong and Andersen, 2011; Kim et al., 2012). Hence firms either behave ethically in many of their dealings or they do not, although social responsibility may be used as a scrutiny-reducing tool and thus managers' motives for ethical behaviour may be less than pure (Calegari et al., 2010). Using a multi-country panel of data, Bozzolan et al. (2015) show that even within the arena of earnings management, firms with good social performance will be more likely to use accrualsbased earnings management than real earnings management, with the latter being more expensive since it distorts the real activities of the firm.

While different philosophical positions have been taken regarding the link between CSR and the tax policies of firms, what are the empirical findings? Unfortunately there is as yet very little hard evidence. Lanis and Richardson (2012) document a negative correlation between 
CSR disclosure levels and effective tax rates while Hoi et al. (2013) find that firms with high levels of social irresponsibility are also more likely to engage in tax sheltering activities and are more aggressively avoiding taxes after controlling for the impacts of a range of other factors. They find, however, no evidence for a link between tax avoidance and measures of social responsibility. On the other hand, a study focusing on US commercial banks finds the level of CSR exhibited by a firm to be positively related to the extent to which it manages its earnings (Grougiou et al., 2014). They attribute their results to the ability of a good record on CSR to act as a smokescreen that draws attention away from dubious accounting practices. Similarly, Kim and Venkatachalam (2011) find that companies engaged in gambling, tobacco or alcohol production industries show higher reporting quality than similar firms in other industries.

Kim et al. (2012) find that a high level of social responsibility is correlated with greater honesty in more traditional accounting measures, such as a lower likelihood of making use of discretionary accruals to manipulate earnings or operating activities and reduced chances of being subject to regulatory investigations. Since Kim et al. control for the level of reputational capital in their models, they argue that this relationship arises because the managers of such firms behave more ethically than others across a range of dimensions.

If we view the avoidance of corporation tax as one aspect of a firm's social performance, then it is also of relevance to question the effect it has on the firm's financial performance, and although the evidence on this issue is rather inconclusive, the consensus appears to be that there is very little link between tax avoidance and stock market performance (Austin and Wilson; 2017; Brooks et al., 2016; Cloyd et al., 2003; Seida and Wempe, 2004). Firms paying the lowest industry-adjusted tax rates have higher stock market risk, however (Brooks et al., 2016; Guenther et al., 2016).

\section{The link between CSP and stock market performance at the firm level}

The first attempts to connect a firm's social responsibility with accounting or market measures of its financial performance were made in the 1970s. As one may imagine, these early empirical studies investigating the CSP-FP relationship were characterised by significant limitations but managed to pave the path for the entire field. 
On the first issue of 'Business and Society Review', Moskowitz (1972) listed 14 companies as being characteristic of exemplary social responsibility and suggested that they ought to be solid investment choices. In the next issue of the same journal, it was observed that these stocks outperformed in terms of total capital returns both the Dow-Jones index and S\&P Industrials index for the elapsed period of six months. Thus, it was argued that there appears to be a positive association between CSR and stock returns. Moskowitz did not control for the risk that this set of stocks bore. He did not perform any statistical analysis to control for the confounding effects that other factors may have had on financial performance. Nor did he try to extend the sample in order to demonstrate that the results were not an outcome of 'cherry picking' those firms that just happened to do good and perform well at the same time. But his article marked the start of a literature which has become larger, richer, more sophisticated, more rigorous and with greater diversity over the course of the subsequent 45 years. ${ }^{10}$

The facet of CSR which has historically received the greatest attention has been the environmental footprint of a company. Belkaoui (1976) is amongst the first to look into the link between a firm's disclosure of environmental policies and the performance of its stock. He compares the returns of a group of 50 US companies whose annual reports included pollution control information with those of 50 randomly selected US firms from the same industries with the former. The results indicate that the companies which include environmental information in their reports underperform the control group before the publication and outperform them afterwards. Similarly, Blacconiere and Northcut (1997) investigate the relation between market reactions to legislative events leading to clean up costs associated with the Superfund Amendments and Reauthorization Act (SARA) of 1986 and environmental information. They provide evidence that 'chemical firms with more extensive environmental disclosures included in their 10-K reports had a less negative reaction to SARA'. The main conclusion of both studies is that environmental information appears to be stock price relevant in financial markets.

Konar and Cohen (2001), on the other hand, focus on the financial impact of environmental performance instead of disclosure. Using an extensive sample of large US firms, they show that toxic emissions are strongly negatively related with a variety of different measures of

\footnotetext{
${ }^{10}$ The Moskowitz prize for Socially Responsible Investing, administered by Haas School of Business, University of California Berkeley, is considered to be one of the most prestigious global awards recognizing outstanding quantitative research in SRI. It is named after Milton Moskowitz in order to honour his pioneering contribution to the field of SRI.
} 
market valuation of corporations, especially so in the traditionally polluting industries. Along the same lines, Thomas (2001) uses UK data finds that 'both the adoption of an environmental policy and prosecution for breach of environment standards' (i.e. both indications of positive and negative environmental corporate performance) are important determinants of a firm's excess returns. Furthermore, Klassen and McLaughlin (1996) provide both a theoretical model and empirical evidence which support the notion that environmental performance awards are associated with significant positive returns whereas environmental crises are linked with significant negative returns. More recently, Graham, Maher, and Northcut (2001), Graham and Maher (2006) and Bauer and Hann (2010) all report findings which support a negative association between environmental risk management and corporate bond ratings or yields. Within a more extensive investigative framework, Sharfman and Fernando (2008) demonstrate that improved corporate environmental performance leads not only to reductions in firms' costs of capital, but also to 'a shift from equity to debt financing and higher tax benefits associated with the ability to add debt'.

Another dimension of a firm's CSP which has received significant attention is its relationship with its employees and the overall level of employee satisfaction. Traditionally, the most frequently used proxy for this attribute comes from the inclusion of a firm in Fortune's 'Best Companies to Work For' list which considers the employee's sense of pride and camaraderie as well as their trust towards the managerial team. Filbeck and Preece (2003) find a statistically significant positive response to the announcement of the constituents of the list and higher long term risk-adjusted returns of these firms compared to a matched sample of companies. The dataset, methodological framework and empirical results of Fulmer, Gerhart, and Scott (2003) are very similar and corroborate the view that strong employee relations can be a source of significant competitive advantage.

The same conclusions are echoed in the work of Edmans (2011), who finds that a portfolio of the "100 Best Companies to Work For in America" earned average abnormal returns of 3.5\% from 1984 to 2009, and Faleye and Trahan (2011), who also document that firms applying labour-friendly practices outperform their peers in terms of long-run stock market returns and operating results. Brammer et al. (2009) also find that firms which are newly included in Business Ethics 'America's Best 100 Corporate Citizens' but which are outside the S\&P500 provide significant positive abnormal returns to stock investors. Lastly, Kane et al. (2005) take a different approach and show that firms with better employee relations (as proxied by the relevant measure in the KLD STATS database) are better at obtaining labour concessions, 
especially in times of economic adversity, and hence face a lower probability of being in financial distress.

Environmental practices and employee relations may be the aspects of firm sustainability whose financial impacts have been investigated most extensively; however, the literature has expanded beyond these dimensions. The relationship of a company with the local communities in which it operates, the safety standards of the products and services offered, its overall charitable contributions, its treatment of diversity issues, minorities, indigenous people's rights and respect for human rights in general, are aspects whose financial effects have also been focal points of academic studies. However, the empirical results concerning which of these aspects of CSR are value creative are not as unequivocal as in the case of environmental performance and employee satisfaction. This may have to do with the underlying nature of each component of CSR. As already mentioned, the foundations of the business case for CSR lie on stakeholder theory. The basic premise is that a firm's relationship with a variety of different constituents (stakeholders) that 'have, or claim, ownership, rights, or interests in a corporation and its activities, past, present, or future' (Clarkson, 1995) can prove to be important contributors to its financial success. However, Clarkson separates stakeholder groups into primary and secondary with the distinction being that the former are absolutely essential to a firm's state, to the point that 'If any primary stakeholder group... becomes dissatisfied and withdraws from the corporate system, in whole or in part, the corporation will be seriously damaged or unable to continue as a going concern'.

Hillman and Keim (2001) make use of this distinction and hypothesise that the financial effects of CSR targeting primary stakeholders will be value-creating whereas CSR focusing on secondary stakeholders may not yield any tangible economic benefits to the firm. They categorise employee relations, diversity issues, product safety issues, community relations and environmental performance as strategic management issues (relevant to primary stakeholders) while dimensions such as involvement with the alcohol/tobacco/gambling, military contracting and nuclear power industry are categorised as social issue participations (and are relevant to secondary stakeholders). Their empirical results suggest that the former characteristics add to the market value of a firm whereas the latter ones deduct from it. Of similar rationale is the work of Chang, Kim, and Li (2014), which follows the framework suggested by Mattingly and Berman (2006). The authors aggregate different dimensions of CSR and also find that 'Technical CSR' (targeting primary stakeholders) is positively associated with both market based and accounting based measures of financial performance. Jiao (2010) also recognises 
that different stakeholders have different economic significance for firms and correspondingly finds that CSR can increase firm market value mainly via improved employee welfare and environmental performance.

In spite of a certain variability in the financial impacts of CSR activities according to the stakeholder group that they relate to (suppliers, employees, customers, regulators, community, environment and others), the overall conclusion is clear when taking a broad view of the literature: there is a positive, statistically significant albeit economically modest association between CSR and financial performance at the firm level. Both previous literature reviews (Malik, 2015; Margolis and Walsh, 2003) and meta-analyses (Friede, Busch, and Bassen, 2015; Lu and Taylor, 2016; Margolis et al., 2009; Orlitzky et al., 2003) document that the majority of studies in this field bring forward evidence of this positive link, with a sizeable number of papers not being able to find a demonstrable link either way (i.e. a 'neutral' association) and only a very small minority (6-8\%) of empirical work finding a negative relationship between the two concepts. ${ }^{11}$ Impressively, the correlations between CSP and FP reported in most metaanalyses are remarkably similar. For example, Orlitzky et al. (2003) find the corrected average correlation coefficient to be 0.15 . Margolis et al. (2009) report this to be approximately 0.13 while most recently, Friede et al. (2015) aggregate data from about 2,200 studies (including working papers) and still find a weighted correlation of almost 0.12 .

Ultimately, although many contemporary studies in the field will argue that no consensus has been reached, the burden of evidence lies heavily on the side of a modest positive link between CSP and FP at the firm level. Given that a case for value-destruction arising from high CSP receives minimal support, it is even easier to state that, at the very least, the CSP-FP association is a non-negative one.

\section{Assessing the performance of SRI portfolios, funds and indices}

According to modern portfolio theory, any attempt to reduce the investment universe in a decidedly non-random way would create a portfolio of assets which is disproportionately exposed to non-systematic risks. Hence, the portfolio's diversification would be sub-optimal and would bear types of risks that are not appropriately compensated and therefore, its riskadjusted returns would be inferior. It is evident that this rationale could easily be applied to

\footnotetext{
${ }^{11}$ See, for example, Brammer et al. (2006) for one example of such a negative view.
} 
SRI portfolios and investment vehicles (Kurtz, 1997). The counterargument to this is that the positive firm level CSP-FP association should at least neutralise any negative diversification effect.

Yet, in spite of the mild positive CSP-FP link at the firm level, the same conclusion cannot be easily extended to the level of a portfolio, fund or index which incorporates environmental, social or governance criteria in the security selection process. Many studies have compared the risk-adjusted performance characteristics of SRI portfolios vis-à-vis otherwise similar conventional portfolios with the results being mixed but usually pointing towards a nonsignificant difference in either direction.

There are examples of earlier studies addressing this issue which are supportive of a wealth increasing effect of CSR in investing portfolios. Derwall et al. (2005) construct and compare two equity portfolios that differ in the eco-efficiency of the constituent firms. They find that over the 1995-2003 period, the portfolio characterised by higher environmental performance is associated with substantially higher returns even after accounting for differences in market sensitivity, investment style and industry-specific exposures. The results of Kempf and Osthoff (2007) are even more striking. They create long-short portfolios (buying stocks of firms with high sustainability ratings and selling those with low CSP) and find that this strategy can lead to abnormal returns of up to $8.7 \%$ per annum. They also document that best-in-class approaches and a focus on positive rather than negative (exclusion) CSP screening criteria produce the best financial results.

However, the aforementioned studies appear to be the exception rather than the rule. The vast majority of empirical investigations of the CSP-FP link at the portfolio level point towards nonsignificant return differences between responsibly screened and conventional portfolios. For example, Renneboog, Ter Horst, and Zhang (2008) collect evidence of the performance of SRI funds from across the world. They find that although SRI funds tend to underperform regional benchmarks (as do most actively managed funds on average), their risk-adjusted returns are statistically indistinguishable from those of their conventional counterparts. Similarly, Laurel (2011) finds that the number of CSP screens used in European funds does not seem to influence their performance either positively or negatively. Derwall and Koedijk (2009) expand the analytical framework to the fixed income market and also find that SRI bond funds have essentially the same performance as conventional bond funds. The respective comparison in balanced funds even reveals a slight (1.3\%) outperformance in favour of SRI investment 
vehicles. The same conclusions hold for the studies focusing on SRI indices. Statman (2006) finds that the alphas of the Domini 400 index (one of the oldest and most well know social equity indexes) between 1990 and 2004 are not any different, in a statistical sense, from those of the S\&P 500 index. Schröder (2007) expands the investigation by looking into the performance of 29 SRI stock indexes and utilising different single-factor and multi-factor models to measure their performance. His results also demonstrate that SRI indexes do not exhibit different risk-adjusted returns from conventional benchmarks, irrespective of the type of screening used.

Overall, there appears to be a consensus in the literature, supported by meta-analyses (Friede et al., 2015; Revelli and Viviani, 2015), that at CSP-screened portfolios neither outperform not underperform conventional portfolios with similar characteristics on a consistent basis. This may seem to contrast with the respective results at the firm level of analysis but there are different ways it can be interpreted. Firstly, it may simply be that the positive (value enhancing or risk reducing) effects of CSP at the firm level are almost exactly counterbalanced by the negative effects of a sub-optimal diversification in SRI portfolios, thus leading to a neutral overall outcome. Secondly, one must not forget that very few studies at the firm level of analysis include transaction costs, fund fees or other frictions whereas this is the norm in portfolio-level studies. These frictions (which can be higher for SRI portfolios) can make the mild positive firm level impact of CSP disappear.

A last note should be made about the so-called 'sin' or 'vice' portfolios. These terms are generally used to refer to investment principles which exclude all firms in sectors which are deemed to be particularly controversial on moral grounds. Typically, the excluded assets are of companies associated with tobacco, alcohol or gambling but the definition is often expanded to firms in firearms, military, nuclear energy and various other businesses. The main practical differences between this type of socially responsible investing and others are that:

i) avoiding sin industries refers exclusively to exclusionary screens (whereas most SRI comprises of a mixture of positive and negative screens) and

ii) this negative screening is imposed on groups of firms which have very similar operational characteristics (as they are of the same sectors).

Statman and Glushkov (2009) show that shunning companies operating in sin industries is associated with a financial disadvantage and offsets any positive financial effect brought about 
by investing in firms with high social responsibility scores. Along the same lines, Hong and Kacperczyk (2009) find that vice stocks receive less coverage by analysts, are less held by norm-constrained institutional investors such as pension plans and excluding them from the investment universe comes with a financial cost. Fabozzi et al. (2008) expand the notion of firms in sin-seeking industries to include not just alcohol, gaming, tobacco and weapons, but also adult services and even biotech alterations. The findings of the study are also demonstrative of the financial costs that come from excluding sin industries. The authors show that 'the sin portfolio produced an annual return of 19\% over the study period, unambiguously outperforming common benchmarks in terms of both magnitude and frequency' (p.92). More recently, Capelle-Blancard and Monjon (2014) verify that sectoral CSR screens (including the avoidance of sin stocks) have a negative impact on portfolio performance. Hence, the bulk of the current evidence - yet not the entirety, see Humphrey and Tan (2014) - suggests that this segment of SRI does come with a financial cost and investors should take this into consideration when allocating their wealth to funds applying such screens.

Having perused the core of the CSP-FP literature and drawn some broad conclusions, it is worth delving deeper and examining some of the finer characteristics of this widely studied relationship.

\section{Stylised characteristics of the link between CSP and financial performance}

\section{CSP and financial risk}

The stakeholder theory framework which has been used to support the existence of a positive link between CSP and FP (Clarkson, 1995; Jones, 1995) could easily be used in a way which implies that improved CSP will lead to value enhancement for the corporation or to a persistent reduction in the risks it faces. Godfrey (2005) argues that CSP can generate a certain 'moral capital' which is used as a reputational shield if the firm finds itself in the midst of controversy. In that way, the company has a higher probability to retain its trustworthiness and preserve its relational wealth with its stakeholders - and, ultimately, its bottom line.

Earlier studies in this research area used risk adjusted performance metrics to gauge the financial impact of CSP without making much effort to identify whether this impact was mainly due to increased returns, lower downside risk or both. Orlitzky and Benjamin's (2001) metaanalysis documents a significant negative mean true-score correlation between CSP and risk of 
-0.21 and shows that the relationship is stronger for market-based measures of risk versus accounting-based measures. The same paper, however, exposes the various dataset and methodological limitations that plagued a significant segment of the body of work up until that time.

In the last 15 years there have been many more efforts to address this issue with multiple studies focusing on the relationship between CSP and financial risk per se from different angles. Godfrey, Merrill and Hansen (2009) test and confirm the risk management properties of strong CSP using an event study analytical framework surrounding legal and regulatory actions taken against firms. Sharfman and Fernando (2008) focus solely on firm environmental performance and show that it can lead to a reduced cost of capital through various pathways including a reduction in systematic risk. Salama, Anderson and Toms (2011) corroborate these findings as they demonstrate that community and environmental responsibility rankings of UK firms are also negatively associated with firm betas. Oikonomou, Brooks and Pavelin (2012) provide further details on the nature of the CSP-systematic risk link. The authors verify the previous results for a sizeable panel data sample using both conventional and downside risk metrics the latter being more indicative of actual investment risk rather than volatility. Interestingly, they find that the negative (i.e. risk increasing) effects of additional social and environmental controversies become stronger during periods of higher market volatility (e.g., a financial crisis). Luo and Bhattacharya (2009) complement the above analyses by zooming in on the effects of CSP on idiosyncratic firm risk and also find a negative association between the two concepts.

It is worth pointing out that although all the above studies investigate the relationship between CSP and risk using the equity markets as the relevant economic laboratory, there is also evidence from examinations of other asset classes. In the bond market, both Bauer and Hann (2010) and Oikonomou, Brooks and Pavelin (2014b) show that corporate bonds of firms with more environmental and CSP strengths respectively have better credit ratings (i.e. lower credit risk) and, consequently, lower yields while the exact opposite is true for firms with more environmental/CSP concerns. Ge and Liu (2015) verify this to be the case even when one looks only into new bond issuance. All these findings are consistent with the innovative work of Goss (2009), who first showed that CSP is a determinant of financial distress. Lastly, Eichholtz, Kok, and Yonder (2012) show that the inverse CSP-risk relationship holds even in the real estate market. Specifically, they find that real estate investment trusts which hold a higher proportion 
of 'green' properties in their portfolios also have, ceteris paribus, significantly lower market betas.

\section{Asymmetry and non-linearity in the CSP-FP link}

A second interesting empirical observation arises when considering the particulars of conceptualising and measuring CSP. More specifically, it is both theoretically plausible and empirically verifiable that most firms will simultaneously exhibit indications of positive and negative CSP. For example, a firm may have embedded a recycling programme in its supply chain but also have significant emissions of greenhouse gases. Given this, the follow-up question is whether such conflicting indications should be combined in a single measure covering the wide spectrum of CSP or whether they should be treated as completely distinct issues with potentially differing impacts on the firms and therefore measures separately (Mattingly and Berman, 2006).

The literature is split on this choice but a fascinating conclusion is often reached when CSP strengths and concerns are not combined in a single measure. It appears that the negative financial impact of concerns is stronger than the positive financial impact of strengths. Lankoski (2009) surveys corporate executives on the issue and indeed finds that their belief is that the adverse economic effects of 'negative externalities' regarding CSP are stronger than the effects of 'positive externalities'. The author argues that this is possibly an effect of the common psychological trait referred to as negativity bias - the observation that negative actions tend to weigh more heavily in people's perceptions than positive actions. Mishina, Block and Mannor (2012) have a different interpretation. They posit that good corporate behaviour is frequently understood simply as a case of meeting societal expectations and conforming with norms and thereby does not convey much information about the true moral character of the firm. Corporate social or environmental controversies on the other hand constitute deviations from the norm and as such are more reflective of a firm's motives and underlying character.

Whatever the explanation may be, studies using different methodological frameworks verify this observation. Wood and Jones (1995) first noted that when event study methodologies were employed in previous papers, the financially harmful effects of CSP were evident whereas announcements regarding high CSP did not bring about particularly strong market reactions. Meijer and Schuyt (2005) investigate the impact of CSP in consumer behaviour and find that customers will react when it drops below a certain acceptable level (by boycotting the firm) 
but above average levels of CSP are not strongly associated with higher product sales. More recently, Mishra and Modi (2013) return to the CSR-risk link and show that there is an unconditional effect of negative CSP in increasing idiosyncratic risk whereas the risk-reducing effect of positive CSP activities is contingent on the financial leverage of the respective firm. The narrative is similar in the context of the study of Kappou and Oikonomou (2016), who find evidence in favour of a 'social index effect': additions of firms to an SRI index do not, on average, cause a statistically significant market reaction whereas deletions from the index (usually because of ethical/responsibility controversies) are associated with negative abnormal returns on the announcement date. Lastly, Krüger's (2015) findings fall perfectly in line with all the above. The author shows that investors react strongly (and negatively) to negative CSP events but positive CSP events cause only statistically and economically weak market responses.

The observations regarding the asymmetry in the CSP-FP link are very interesting as are the conclusions reached by several other studies which investigate the true functional form of this relationship. Most of the empirical literature makes the implicit assumption that the relationship between the two variables will be linear in nature. But a few studies have questioned this premise and have yielded fascinating results.

Barnett and Salomon (2006) conduct a novel analysis which shows that SRI funds with very few or many environmental, social and governance (ESG) screening criteria clearly outperform funds with an intermediate number of such filters. This emerging picture is that of a non-monotonic, U-shaped link between CSP and FP with the worst risk-adjusted performance being associated with funds which utilise seven ESG screens. The authors argue that this is likely because funds with very few ESG screens can effectively diversify most of the unrewarded unsystematic risk while funds with many ESG screens are beneficiaries of the positive value-enhancing CSP effects outlined in previous literature. In comparison, funds with an intermediate number of ESG screens are getting 'caught in the middle' and do not achieve much on either front which inevitably leads to financial underperformance vis-à-vis their competitors.

Brammer and Millington (2008) reach similar conclusions. The authors group firms according to the extent of their charitable donations and find that firms with either unusually high or unusually low charitable giving tend to, ceteris paribus, financially outperform other firms. More specifically, firms with very low donations seem to do better than their peers in the short- 
run due to cost efficiency while firms with high donations seem to outperform in the longer run - consistent with the rationale of dedicating resources to build superior relationships with stakeholders that eventually pay off. Barnett and Salomon's (2012) study corroborates and generalises these findings as it unveils a U-shaped, firm-level link between a multidimensional measurement of CSP and FP link - and for a large panel data sample of observations. Lastly, on a slightly different note, Oikonomou, Brooks and Pavelin (2014a) show that groups of firms which provide unequivocal indications of CSP strengths manage to produce very high financial returns, firms which are solely associated with CSP concerns perform a bit worse but still quite well, whereas the group of firms which provide indication of mixed social performance (with both strengths and concerns at the same time) significantly underperform both other groups. Though this line of empirical work still requires additional analyses to take place in order for a clear consensus to emerge, it demonstrates that the CSP-FP link is likely to be much more complex in nature than originally hypothesised.

\section{The effects of CSP on corporate finance decisions}

It is clear that the literature has reached a stage of maturity which requires it to move from the questions of 'if' CSP influences firm financial performance to 'how exactly' it manages to do so and hence newer studies are zooming in more closely on the potential impact CSP has on some of the most important corporate decisions that are taken. One of the most recent streams of research within the wider area investigates the association of CSP with major corporate decisions regarding, for example, the type and level of executive remuneration or the firm's involvement in mergers and acquisitions.

There are various possible theoretical connections between a firm's social/environmental policies and the level (or type) of executive remuneration. Competing hypotheses can motivate such empirical investigations via completely different pathways. The potential of higher CSP to lead to improved stakeholder management and more effective conflict resolution with stakeholders should also lead to a greater overall compensation for top firm managers. In addition, given that the tangible financial results of high CSP are expected to accrue in the long-run, one would anticipate that there would also be a positive association between CSP and long-term corporate incentives such as stock options (with a reasonable vesting period). But the other side of this argument is that there may be a sharp contrast between the top management's view of CSP and that of the board of directors - which generally control the managing executives' compensation. If the board believes that the application of principles and 
policies which increase a firm's CSP is against the best interests of shareholders and merely serves the personal ethical agenda of the CEO then a negative CSP-CEO remuneration link will emerge. Furthermore, it may be that efforts to increase CSP are disingenuous greenwashing attempts (what Godfrey (2005) would call 'ingratiating stakeholders') and this will financially backfire.

Perhaps both rationales being partly true explains the mixed results of the existing literature in this sub-topic. Early work by McGuire, Dow and Argheyd (2003) showed that remuneration incentives as a whole are not significantly linked to CSP but salary and long-term incentives are associated with weak social performance. Mahoney and Thorn (2006) on the other hand conduct their analysis on a small sample of Canadian firms and find that executives' salary is positively connected to CSP weaknesses but bonuses and stock options are related to CSP strengths. More recent research is also equivocal in its conclusions. Berrone and Gomez-Mejia (2009) focus exclusively on firm environmental performance and find that it is associated with higher CEO pay. They also provide evidence that long-term pay structures lead to improved pollution prevention success, especially in highly polluting industries. But contrary to these results, Cai, Jo and Pan (2011) show that lagged CSP is inversely related to total and cash CEO compensation. Very similar conclusions are also reached by Miles and Miles (2013).

Lastly, the role of CSP/sustainability in the market for corporate control has started receiving some attention. Given how important capability transfer, resource sharing, shared values and trust are in realising merger synergies, it seems very intuitive that CSP will influence the integration process and the overall success of a deal (Deloitte, 2009). Currently, there are only two major published studies investigating this issue. Aktas, De Bodt, and Cousin (2011) show that for a modest sample of international M\&A deals, the stock market reacts positively when the target firm is characterised by a higher level of CSP. Interestingly, they also find that the CSP of the acquirer appears to increase, on average, after the deal, thus indicating a 'learning process' coming into effect and running from the target to the acquirer in this regard. The work of Deng et al. (2013) complements and strengthens the relevance of CSP in the outcome of mergers and acquisitions. Using a much larger sample of US deals, the authors find that acquirers with higher CSP realise higher announcement returns, higher long-term returns and higher post-merger long-term operating performance. In addition, the probability of a deal being completed is higher for high CSP acquirers and for them the time needed for this completion is lower. 


\section{Conclusions and contributions of this special issue to the literature}

In a nutshell, based on our review of the burgeoning literature studying the link between $\mathrm{CSP} / \mathrm{ESG}$ and financial performance, we have drawn a series of conclusions which summarise the key findings of 45 years of empirical research in accounting and finance. These are:

i) ESG disclosures are generally associated with better ESG performance as well as firm performance.

ii) There is a positive and statistically significant but economically modest link between CSP and financial performance at the firm level.

iii) The risk-adjusted performance of SRI funds and indexes is statistically indistinguishable from that of conventional funds and indexes.

iv) Screening out so-called 'sin industries' appears to come at a financial cost.

v) There is a strong negative causal link running from CSP to various types of financial risk (systematic, idiosyncratic, default and others) and this is observable in different markets and asset classes.

vi) There is asymmetry in the financial impacts of CSP whereby the negative financial effects of corporate social irresponsibility are stronger than the positive financial effects of corporate social responsibility.

vii) The shape of the relationship between CSP and financial performance (linear or non-linear and what type of non-linearity) is not clear.

viii) ESG/CSP appears to be related to and influence important corporate decisions such as executive remuneration and mergers and acquisitions.

All the above taken together are indicative of the state that the literature has reached: We have now aggregated a significant amount of empirical evidence about the sign and strength of the relationship between ESG disclosures and performance and financial bottom line of the firm (or its marketable financial assets). Though the literature is slow to admit it, a certain consensus has been reached and we have a reasonable idea of what the 'big picture' looks like. But there is still a lot to learn about the exact shape of this relationship, the contingencies and dynamic components that alter it, the moderating and mediating factors that may play important roles and the corporate decisions related to or brought upon by the policies, processes, procedures and overall culture certain levels of ESG dictate. 
This special issue hopes to contribute in these directions. In the opening paper, Bernardi and Stark make use of a natural experimental setting and study whether the change of reporting regime in South Africa - with the introduction of the legal mandate for ESG disclosures - had any effect on the accuracy of analysts' forecasts of earnings. They find that ESG disclosure levels, particularly environmental ones, are indeed associated with improved forecast accuracy. On the other hand, in the second paper of this special issue, Baboukardos attempts to disentangle the links between environmental disclosures, environmental performance and market valuations. He shows that balance sheet environmental provisions play a moderating role between actual environmental performance and market value of the firm, i.e. investors place greater value on corporate environmental ratings when they are accompanied by environmental provisions versus when they are not. In the next paper of the issue, Broadstock et al specifically focus on reported greenhouse gas emissions and reveal that, at least in the UK setting, there is a non-linear connection (inverse U-shaped) that can be found between such emissions and business performance. Furthermore, the authors show that the decision to report emissions is actually not influenced by social or corporate governance disclosure attitudes.

The following two papers explore the role of the principal decision maker of any large corporation - the CEO - in the interplay between ESG and firm value. Li et al verify the positive link between ESG disclosures and market valuations and contribute to the literature by showing that this link is strengthened when CEO power in the firm is higher - possibly because it produces a signal that more ESG disclosures will also lead to better ESG performance, driven by the decisions of the CEO. A different angle is investigated by Bouslah et al. The authors look into the ways that managerial incentives influence a firm's ESG performance. They find that in the period before the latest financial crisis in the US, executive remuneration that rewarded higher risk-taking from the CEO was positively associated with ESG controversies and socially irresponsible activities (which have been shown to increase firm risk). Lastly, Huang et al focus on corporate governance aspects of the firm and provide a nuanced framework relating monitoring mechanism and managerial incentives to the use of currency and interest rate derivative securities on the part of the corporation. 


\section{References}

Abbott, W.F. and Monsen, R.J. (1979) On the measurement of corporate social responsibility: self-reported disclosures as a method of measuring corporate involvement Academy of Management Journal 22(3), 501-515.

Adams, S. and Simnett, R. (2011) Integrated reporting: an opportunity for Australia's not-forprofit sector Australian Accounting Review 21, 292-301.

Aerts, W. and Cormier, D. (2009) Media legitimacy and corporate environmental communication Accounting, Organizations and Society 34, 1-27.

Aktas, N., De Bodt, E., and Cousin, J.-G. (2011). Do financial markets care about SRI? Evidence from mergers and acquisitions Journal of Banking and Finance 35(7), 1753-1761.

Al-Tuwaijri, S.A., Christensen, T.E. and Hughes, K.E II (2004) The relations among environmental disclosure, environmental performance, and economic performance: a simultaneous equations approach Accounting, Organizations and Society 29, 447-471.

Andrews, B.H., Gul, F.A., Guthrie, J.E. and Teoh, H.Y. (1989) A note on corporate social disclosure practices in developing countries: The case of Malaysia and Singapore British Accounting Review 21(4), 371-376.

Austin, C. R., and Wilson, R. J. (2017). An Examination of Reputational Costs and Tax Avoidance: Evidence from Firms with Valuable Consumer Brands Journal of the American Taxation Association 39(1), 67-93.

Barnett, M. L., and Salomon, R. M. (2006). Beyond dichotomy: The curvilinear relationship between social responsibility and financial performance Strategic Management Journal 27(11), 1101-1122.

Barnett, M. L., and Salomon, R. M. (2012). Does it pay to be really good? Addressing the shape of the relationship between social and financial performance Strategic Management Journal 33(11), 1304-1320.

Bauer, R., and Hann, D. (2010). Corporate environmental management and credit risk Available at SSRN 1660470.

Bebbington, K.J. and Gray, R. (2001) An account of sustainability: failure, success and reconceptualisation Critical Perspectives on Accounting 12, 557-587.

Bebbington, K.J. and Thomson, I. (1996) Business Conceptions of Sustainability and the Implications for Accountancy ACCA, London.

Belkaoui, A. (1976). The Impact of the Disclosure of the Environmental Effects of Organizational Behavior on the Market Financial Management 5(4), 26.

Belkaoui, A. and Karpik, P.G. (1989) Determinants of the corporate decision to disclose social information Accounting, Auditing and Accountability Journal 2(1), 36-51. 
Berrone, P., and Gomez-Mejia, L. R. (2009). Environmental performance and executive compensation: An integrated agency-institutional perspective Academy of Management Journal 52(1), 103-126.

Blacconiere, W. G., and Northcut, W. D. (1997). Environmental Information and Market Reactions to Environmental Legislation Journal of Accounting, Auditing and Finance 12(2), $149-178$.

Boot, A.W., Greenbaum, S.I., and Thakor, A.V. (1993) Reputation and discretion in financial contracting American Economic Review 83(5), 1165-1183.

Bozzolan, S., Fabrizi, M., Mallin, C., and Michelon, G. (2015) Corporate social responsibility and earnings quality: International evidence International Journal of Accounting 50, 361396.

Bragdon, J. and Marlin, J. (1972) Is pollution profitable? Risk Management 19, 9-18.

Brammer, S., Brooks, C. and Pavelin, S. (2006) Corporate social performance and stock returns: UK evidence from disaggregate measures Financial Management 35(3), 97-116.

Brammer, S., Brooks, C. and Pavelin, S. (2009) The stock performance of America's 100 best corporate citizens Quarterly Review of Economics and Finance, 49(3), 1065-1080.

Brammer, S., and Millington, A. (2008). Does it pay to be different? An analysis of the relationship between corporate social and financial performance Strategic Management Journal 29(12), 1325-1343.

Brammer, S. and Pavelin, S. (2006) Voluntary environmental disclosures by large UK companies Journal of Business Finance and Accounting 33(7\&8), 1168-1188.

Brooks, C., Godfrey, C., Hillenbrand, C. and Money, K. (2016) Do investors care about corporate tax? Journal of Corporate Finance 38, 218-248.

Brown, N. and Deegan, C. (1998) The public disclosure of environmental performance information: a dual test of media agenda setting theory and legitimacy theory Accounting and Business Research 29(1), 21-41.

Buhr, N. (2002) A structuration view on the initiation of environmental reports Critical Perspectives on Accounting 13(1), 17-38.

Burritt, R.L. and Schaltegger, S. (2010) Sustainability accounting and reporting: fad or trend? Accounting, Auditing and Accountability Journal 23(7), 829-846.

Cai, Y., Jo, H., and Pan, C. (2011). Vice or virtue? The impact of corporate social responsibility on executive compensation Journal of Business Ethics 104(2), 159-173.

Calegari, M.F., Chotigeat, T. and Harjoto, M.A. (2010) Corporate social responsibility and earnings reporting Journal of Current Research in Global Business 13, 1-14. 
Campbell, J. (2007) Why would corporations behave in socially responsible ways? An institutional theory of social responsibility Academy of Management Review 32, 946-967.

Capelle-Blancard, G., and Monjon, S. (2014). The performance of socially responsible funds: does the screening process matter? European Financial Management 20(3), 494-520.

Carroll, A. (1979) A three-dimensional conceptual model of corporate performance Academy of Management Review 4(4), 497-505.

Chang, K., Kim, I., and Li, Y. (2014). The heterogeneous impact of corporate social responsibility activities that target different stakeholders Journal of Business Ethics 125(2), 211-234.

Chopra, S. and Wu, P-J. (2016) Eco-activities and operating performance in the computer and electronics industry European Journal of Operational Research 248, 971-981.

Christensen, D.M. (2016) Corporate accountability reporting and high-profile misconduct Accounting Review 91(2), 377-399.

Clarkson, M. E. (1995). A stakeholder framework for analyzing and evaluating corporate social performance Academy of Management Review 20(1), 92-117.

Clarkson, P.M., Li, Y., Richardson, G.D. and Vasvari, F.P. (2008) Revisiting the relation between environmental performance and environmental disclosure: An empirical analysis Accounting, Organizations and Society 33, 303-327.

Cloyd, C B, Mills, L F and Weaver, C D (2003) Firm valuation effects of the expatriation of US corporations to tax haven countries Journal of the American Taxation Association, 25(Supplement), 87-109.

Cormier, D., Ledoux, M.J. and Magnan, M. (2011) The informational contribution of social and environmental disclosures for investors Management Decision 49(8), 1276-1304.

Cormier, D. and Magnan, M. (1999) Corporate environmental disclosure strategies: determinants, costs and benefits Journal of Accounting, Auditing and Finance 14(4), 429451 .

Collett Miles, P., and Miles, G. (2013). Corporate social responsibility and executive compensation: Exploring the link Social Responsibility Journal 9(1), 76-90.

de Villiers, C. and Alexander. D. (2014) The institutionalisation of corporate social responsibility reporting British Accounting Review 46, 198-212.

Deng, X., Kang, J., and Low, B. S. (2013). Corporate social responsibility and stakeholder value maximization: Evidence from mergers Journal of Financial Economics 110(1), 87109.

Derwall, J., Guenster, N., Bauer, R., and Koedijk, K. (2005). The eco-efficiency premium puzzle Financial Analysts Journal 61(2), 51-63. 
Derwall, J., and Koedijk, K. (2009). Socially Responsible Fixed-Income Funds Journal of Business Finance and Accounting 36(1-2), 210-229.

Dye, R.A. (1985) Disclosure of non-proprietary information Journal of Accounting Research 23(1), 123-145.

Dyllick, T. and Hockerts, K. (2002) Beyond the business case for corporate sustainability Business Strategy and the Environment 11, 130-141.

Edmans, A. (2011). Does the stock market fully value intangibles? Employee satisfaction and equity prices Journal of Financial Economics 101(3), 621-640.

Eichholtz, P., Kok, N., and Yonder, E. (2012). Portfolio greenness and the financial performance of REITs Journal of International Money and Finance 31(7), 1911-1929.

Fabozzi, F. J., Ma, K. C., and Oliphant, B. J. (2008). Sin stock returns Journal of Portfolio Management 35(1), 82-94.

Faleye, O., and Trahan, E. A. (2011). Labor-friendly corporate practices: Is what is good for employees good for shareholders? Journal of Business Ethics 101(1), 1-27.

Filbeck, G., and Preece, D. (2003). Fortune's best 100 companies to work for in America: Do they work for shareholders? Journal of Business Finance and Accounting 30(5-6), 771-797.

Fortanier, F., Kolk, A., and Pinkse, J. (2011) Harmonization in CSR reporting: MNEs and global CSR standards Management International Review 51, 665-696.

Frankel, R., McNichols, M. and Wilson, P. (1995) Discretionary disclosure and external financing Accounting Review 70, 135-150.

Freedman, M. and Jaggi, M. (1988) An analysis of the association between pollution disclosure and economic performance Accounting, Auditing and Accountability Journal 1(2), $43-58$.

Freedman, M. and Jaggi, M. (2004) Carbon dioxide emissions and disclosures by electric utilities Advances in Public Interest Accounting 10, 105-129.

Freedman, M. and Jaggi, M. (2011) Global warming disclosures: the impact of the Kyoto Protocol across countries Journal of International Financial Management Accounting 22, 46-90.

Freeman, R. E. (1983). Strategic management: A stakeholder approach Advances in Strategic Management 1(1), 31-60.

Friede, G., Busch, T., and Bassen, A. (2015). ESG and financial performance: aggregated evidence from more than 2000 empirical studies Journal of Sustainable Finance and Investment 5(4), 210-233. 
Friedman, M. (1970). The social responsibility of business is to increase its profits New York Times Magazine 13, 32-33.

Frost, G., Jones, S., Loftus, J. and Laan, S. (2005) A survey of sustainability reporting practices of Australian reporting entities Australian Accounting Review 15, 89-96.

Fulmer, I. S., Gerhart, B., and Scott, K. S. (2003). Are the 100 best better? An empirical investigation of the relationship between being a 'great place to work' and firm performance Personnel Psychology 56(4), 965-993.

Ge, W., and Liu, M. (2015). Corporate social responsibility and the cost of corporate bonds Journal of Accounting and Public Policy 34(6), 597-624.

Godfrey, P. C. (2005). The relationship between corporate philanthropy and shareholder wealth: A risk management perspective Academy of Management Review 30(4), 777-798.

Godfrey, P. C., Merrill, C. B., and Hansen, J. M. (2009). The relationship between corporate social responsibility and shareholder value: An empirical test of the risk management hypothesis Strategic Management Journal 30(4), 425-445.

Goss, A. (2009). Corporate social responsibility and financial distress Proceedings of the Administrative Sciences Association of Canada.

Graham, A., and Maher, J. J. (2006). Environmental liabilities, bond ratings, and bond yields. Advances in Environmental Accounting and Management 3, 111-142.

Graham, A., Maher, J. J., and Northcut, W. D. (2001). Environmental Liability Information and Bond Ratings Journal of Accounting, Auditing and Finance 16(2), 93-116.

Gray, R.H. (2002) Of messiness, systems and sustainability: towards a more social and environmental finance and accounting British Accounting Review 34, 357-386.

Gray, R. (2010) Is accounting for sustainability actually accounting for sustainability ... and how would we know? An exploration of narratives Accounting, Organizations and Society $35,47-62$.

Gray, R.H. and Bebbington, K.J. (2000) Environmental accounting, managerialism and sustainability: is the planet safe in the hands of business and accounting? Advances in Environmental Accounting and Management 1, 1-44.

Gray, R., Kouhy, R. and Lavers, S. (1995) Corporate social and environmental reporting: A review of the literature and a longitudinal study of UK disclosure Accounting, Auditing and Accountability Journal 8(2), 47-77.

Greening, D. and Turban, D. (2000) Corporate social performance as a competitive advantage in attracting a quality workforce Business and Society 39, 254-280. 
Griffin, J.J. and Mahon, J.F. (1997). The corporate social performance and corporate financial performance debate twenty-five years of incomparable research Business and Society 36(1), 5-31.

Grougiou, V., Leventis, S., Dedoulis, E. and Owusu-Ansah, S. (2014) Corporate social responsibility and earnings management in US banks Accounting Forum 38, 155-169.

Guenther, D. A., Matsunaga, S. R., and Williams, B. M. (2016) Is tax avoidance related to firm risk? Accounting Review 92(1), 115-136.

Guthrie, J.E. and Parker, L.D. (1989) Corporate social disclosure reporting: a rebuttal of legitimacy theory Accounting and Business Research 9, 343-352.

Guthrie, J.E. and Parker, L.D. (1990) Corporate social disclosure practice: a comparative international analysis Advances in Public Interest Accounting 3, 159-176.

Haddock, J. (2005) Consumer influence on internet-based corporate communication of environmental activities: the UK food sector British Food Journal 107, 792-805.

Hahn, R. and Kühnen, M. (2013) Determinants of sustainability reporting: a review of results, trends, theory, and opportunities in an expanding field of research Journal of Cleaner Production 59, 5-21.

Hart, S.L. (1995) A natural resource-based view of the firm Academy of Management Review 20(4), 986-1014.

Hasseldine, J. and Morris, G. (2013) Corporate Social Responsibility and Tax Avoidance: A Comment and Reflection Accounting Forum 37, 1-14.

Healy, P.M. and Palepu, K.G. (2001) Information asymmetry, corporate disclosure and the capital markets: A review of the empirical disclosure literature Journal of Accounting and Economics 31, 405-440.

Hemingway, C. and Maclagan, P. (2004) Managers' personal values as drivers of corporate social responsibility Journal of Business Ethics 50(1), 33-44.

Hess, D. and Dunfee, T.W. (2007) The Kasky-Nike threat to corporate social reporting: implementing a standard of optimal truthful disclosure as a solution Business Ethics Quarterly 17, 5-32.

Hillman, A. J., and Keim, G. D. (2001). Shareholder value, stakeholder management, and social issues: what's the bottom line? Strategic Management Journal 22(2), 125-139.

Hodder-Webb, L., Cohen, J.R., Nath, L., and Wood, D. (2009) The supply of corporate social responsibility disclosures among US firms Journal of Business Ethics 84, 497-527.

Hogner, R.H. (1982) Corporate social reporting: eight decades of development at US Steel. In Preston, L.D. (ed.) Research in Corporate Social Performance and Policy, pp. 243-250, JAI Press, Greenwich. 
Hoi, C-K., Wu, Q. and Zhang, H. (2013) Is corporate social responsibility (CSR) associated with tax avoidance? Evidence from irresponsible CSR activities Accounting Review 88(6) 2025-2059.

Hong, H., and Kacperczyk, M. (2009). The price of sin: The effects of social norms on markets Journal of Financial Economics 93(1), 15-36.

Hong, Y. and Andersen, M.L. (2011) The relationship between corporate social responsibility and earnings management: An exploratory study Journal of Business Ethics 104(4), 461-471.

Humphrey, J. E., and Tan, D. T. (2014). Does it really hurt to be responsible? Journal of Business Ethics 122(3), 375-386.

Ioannou, I. and Serafeim, G. (2016) The consequences of mandatory corporate sustainability reporting: Evidence from four countries Mimeo., London Business School.

Jones, T. (1995) Instrumental stakeholder theory: A synthesis of ethics and economics Academy of Management Review 20(2), 404-437.

Kane, G. D., Velury, U., and Ruf, B. M. (2005). Employee relations and the likelihood of occurrence of corporate financial distress Journal of Business Finance and Accounting 32(56), 1083-1105.

Kappou, K., and Oikonomou, I. (2016). Is there a gold social seal? The financial effects of additions to and deletions from social stock indices Journal of Business Ethics 133(3), 533552.

Kempf, A., and Osthoff, P. (2007). The effect of socially responsible investing on portfolio performance European Financial Management 13(5), 908-922.

Kassinis, G.I. and Soteriou, A.C. (2003) Greening the service profit chain: the impact of environmental management practices Production and Operations Management 12(3), 386403.

Kim, I. and Venkatachalam, M. (2011) Are sin stocks paying the price for accounting sins? Journal of Accounting, Auditing and Finance 26(2), 415-442.

Kim, Y., Park, M.S. and Wier, B. (2012) Is earning quality associated with corporate social responsibility? Accounting Review 87(3), 761-796.

Klassen, R. D., and McLaughlin, C. P. (1996). The impact of environmental management on firm performance Management Science 42(8), 1199-1214.

Kolb, A. (2010) Trajectories of sustainability reporting by MNCs Journal of World Business $45,367-374$.

Konar, S., and Cohen, M. A. (2001). Does the market value environmental performance? Review of Economics and Statistics 83(2), 281-289. 
Krüger, P. (2015). Corporate goodness and shareholder wealth Journal of Financial Economics 115(2), 304-329.

Kurtz, L. (1997). No Effect, or No Net Effect? Studies on Socially Responsible Investing (Digest Summary) Journal of Investing 6(4), 37-49.

Lamberton, G. (2005) Sustainability accounting - a brief history and conceptual framework Accounting Forum 29, 7-26.

Lanis, R. and Richardson, G. (2012) Corporate social responsibility and tax aggressiveness: An empirical analysis Journal of Accounting and Public Policy 31(1), 86-108.

Lankoski, L. (2009). Differential Economic Impacts of Corporate Responsibility Issues Business and Society 48(2), 206-224.

Laurel, D. (2011). Socially responsible investments in Europe: The effects of screening on risk and the clusters in the fund space $S S R N, 1883427$.

Lu, W. and Taylor, M.E. (2016) Which factors moderate the relationship between sustainability performance and financial performance? A meta-analysis study Journal of International Accounting Research 15(1), 1-15.

Luo, L. and Tang, Q. (2014) Does voluntary carbon disclosure reflect underlying carbon performance? Journal of Contemporary Accounting and Economics 10, 191-205.

Luo, X., and Bhattacharya, C. B. (2009). The debate over doing good: Corporate social performance, strategic marketing levers, and firm-idiosyncratic risk Journal of Marketing 73(6), 198-213.

Lys, T., Naughton, J.P. and Wang, C. (2015) Signaling through corporate accountability reporting Journal of Accounting and Economics 60, 56-72.

Mahoney, L. S., and Thorn, L. (2006). An examination of the structure of executive compensation and corporate social responsibility: A Canadian investigation Journal of Business Ethics 69(2), 149-162.

Malik, M. (2015). Value-enhancing capabilities of CSR: A brief review of contemporary literature. Journal of Business Ethics 127(2), 419-438.

Maltby, J. (2004) Hadfields Ltd: its annual general meetings 1903-1939 and their relevance for contemporary social reporting British Accounting Review 415-439.

Margolis, J. D., Elfenbein, H. A., and Walsh, J. P. (2009). Does It Pay to be Good? A Metaanalysis and Redirection of research on the Relation between Corporate Social and Financial Performance Working paper, Harvard University.

Margolis, J. D., and Walsh, J. P. (2003). Misery loves companies: Rethinking social initiatives by business Administrative Science Quarterly 48(2), 268-305. 
Matthews, M.R. (1997) Twenty five years of social and environmental accounting research: is there a silver jubilee to celebrate? Accounting, Auditing and Accountability Journal 10(4), $481-531$.

Mattingly, J. E., and Berman, S. L. (2006). Measurement of corporate social action discovering taxonomy in the Kinder Lydenburg Domini ratings data Business and Society, $45(1), 20-46$.

Maunders, K. and Burritt, R.L. (1991) Accounting and ecological crisis Accounting, Auditing and Accountability Journal 4(3), 9-26.

McGuire, J., Dow, S., and Argheyd, K. (2003). CEO incentives and corporate social performance Journal of Business Ethics 45(4), 341-359.

Meijer, M.-M., and Schuyt, T. (2005). Corporate social performance as a bottom line for consumers Business and Society 44(4), 442.

Milne, M.J. (1996) On sustainability: the environment and management accounting Management Accounting Research 7(1), 135-161.

Mishina, Y., Block, E. S., and Mannor, M. J. (2012). The path dependence of organizational reputation: How social judgment influences assessments of capability and character Strategic Management Journal 33(5), 459-477.

Mishra, S., and Modi, S. B. (2013). Positive and negative corporate social responsibility, financial leverage, and idiosyncratic risk Journal of Business Ethics 117(2), 431-448.

Moser, D.V. and Martin, P.R. (2012) A broader perspective on corporate social responsibility research in accounting Accounting Review 87(3), 797-806.

Moskowitz, M. (1972). Choosing socially responsible stocks Business and Society Review 1(1), 71-75.

Nelling, E. and Webb, E. (2009) Corporate social responsibility and financial performance: the virtuous circle revisited Review of Quantitative Finance and Accounting 32(2), 197-209.

Norris, G. and O’Dwyer, B. (2004) Motivating socially responsible decision making: the operation of management controls in a socially responsive organisation British Accounting Review 36, 173-196.

O'Dwyer, B. (2001) The legitimacy of accountants participation in social and ethical accounting, auditing and reporting Business Ethics: A European Review 10(1), 27-39.

Oikonomou, I., Brooks, C., and Pavelin, S. (2012). The Impact of Corporate Social Performance on Financial Risk and Utility: A Longitudinal Analysis Financial Management 41(2), 483-515.

Oikonomou, I., Brooks, C. and Pavelin, S. (2014a), The Financial Effects of Uniform and Mixed Corporate Social Performance Journal of Management Studies 51, 898-925. 
Oikonomou, I., Brooks, C., and Pavelin, S. (2014b). The Effects of Corporate Social Performance on the Cost of Corporate Debt and Credit Ratings Financial Review 49(1), 4975.

Orlitzky, M., and Benjamin, J. D. (2001). Corporate social performance and firm risk: A meta-analytic review Business and Society 40(4), 369-396.

Orlitzky, M., Schmidt, F.L. and Rynes, S.L. (2003) Corporate social and financial performance: A meta-analysis Organizational Studies 24, 403-441.

Owen, D., Swift, T. and Hunt, K. (2001) Questioning the role of stakeholder engagement in social and ethical accounting, auditing and reporting Accounting Forum 25(3), 264-282.

Parsa, s. and Kouhy, R. (2008) Social reporting by companies listed on the alternative investment market Journal of Business Ethics 79, 345-360.

Patten, D. (2002) The relation between environmental performance and environmental disclosure: A research note Accounting, Organizations and Society 27, 763-773.

Peloza, J. (2006) Using corporate social responsibility as insurance for financial performance California Management Review 48, 52-72.

Puxty, A.G.(1991) Social accountability and universal pragmatics Advances in Public Interest Accounting 4, 35-46.

Qiu, Y., Shaukat, A. and Tharyan, R. (2016) Environmental and social disclosures: Link with corporate financial performance British Accounting Review 48, 102-116.

Renneboog, L., Ter Horst, J., and Zhang, C. (2008). The price of ethics and stakeholder governance: The performance of socially responsible mutual funds Journal of Corporate Finance 14(3), 302-322.

Revelli, C., and Viviani, J.-L. (2015). Financial performance of socially responsible investing (SRI): what have we learned? A meta-analysis Business Ethics: A European Review 24(2), 158-185.

Roberts, R.W. (1992) Determinants of corporate social responsibility disclosure Accounting, Organizations and Society 17(6), 595-612.

Russo, M.V. and Fouts, P.A. (1997) A resource-based perspective on corporate environmental performance and profitability Academy of Management Journal 40(3), 534559.

Salama, A., Anderson, K., and Toms, J. S. (2011). Does community and environmental responsibility affect firm risk? Evidence from UK panel data 1994-2006 Business Ethics: A European Review 20(2), 192-204. 
Schaltegger, S. and Burritt, R.L. (2010) Sustainability accounting for companies:

Catchphrase or decision support for business leaders? Journal of World Business 45, 375384.

Schröder, M. (2007). Is there a difference? The performance characteristics of SRI equity indices Journal of Business Finance and Accounting 34(1-2), 331-348.

Seida, J A and Wempe, W F (2004) Effective tax rate changes and earnings stripping following corporate inversion National Tax Journal, 57(4), 805-28.

Sharfman, M. P., and Fernando, C. S. (2008). Environmental risk management and the cost of capital Strategic Management Journal 29(6), 569-592.

Sikka, P. (2010) Smoke and mirrors: Corporate social responsibility and tax avoidance Accounting Forum 34, 153-168.

Simnett, R., Vanstaelen, A. and Chua, W.F. (2009) Assurance on sustainability reports: An international comparison Accounting Review 53(1), 94-111.

Sinclair-Desgagné, B. and Gozlan, E. (2003) A theory of environmental risk disclosure Journal of Environmental Economics and Management 45(2), 377-393.

Stanny, E. and Ely, K. (2008) Corporate environmental disclosures about the effects of climate change Corporate Social Responsibility and Environmental Management 15, 338348 .

Statman, M. (2006). Socially responsible indexes Journal of Portfolio Management 32(3), $100-109$.

Statman, M., and Glushkov, D. (2009). The wages of social responsibility Financial Analysts Journal 65(4), 33-46.

Stevens, W. (1984) Market reaction to corporate environmental performance Advances in Accounting 1, 41-61.

Teoh, H.Y. and Thong, G. (1984) Another look at corporate social responsibility and reporting: an empirical study in a developing country Accounting, Organizations and Society 9(2), 189-206.

Thomas, A. (2001). Corporate environmental policy and abnormal stock price returns: an empirical investigation Business Strategy and the Environment 10(3), 125-134.

Topping, N. (2012) How does sustainability disclosure drive behavior change? Journal of Applied Corporate Finance 24(2), 45-48.

Ullman, A.E.(1985) Data in search of a theory: a critical examination of the relationships among social performance, social disclosure and economic performance of US firms Academy of Management Review 10(3), 540-557. 
Waddock, S.A. and Graves, S.B. (1997) The corporate social performance - financial performance link Strategic Management Journal 18(4), 303-319.

Willis, A. (2003) The role of Global Reporting Initiative's Sustainability Guidelines in the social screening of investments Journal of Business Ethics 43(3), 233-237.

Wood, D. J., and Jones, R. E. (1995). Stakeholder mismatching: A theoretical problem in empirical research on corporate social performance International Journal of Organizational Analysis 3(3), 229-267. 